\title{
Kontruksi Perempuan dalam Media Baru: Analisis Semiotik Meme Ibu-Ibu Naik Motor di Media Sosial
}

\author{
Yanti Dwi Astuti \\ Universitas Islam Negeri Sunan Kalijaga \\ yantiastuti@uin-suka.ac.id
}

\begin{abstract}
Abstrak
Tingginya pemanfaatan internet dan media sosial melahirkan fenomena munculnya kreativitas warganet menciptakan berbagai parody gambar (meme) untuk mengekspresikan perasaan, kondisi dan mengkritisi sebuah fenomena. Meme telah membuka jalan baru untuk mengkombinasikan berbagai unsur seperti kreatifitas, seni, pesan dan humor kedalam budaya internet. Salah satu fenomena meme ibu-ibu naik motor lebih menekankan unsur parody yang cenderung hyperrealitas, hiperbola dan repetisi sehingga kasus ini menarik dan layak diteliti lebih lanjut karena media bukanlah sebuah saluran yang bebas, ia juga subjek yang mengonstruksi realitas, lengkap dengan pandangan, bias, dan pemihakannya. Penelitian ini menggunakan metode analisis semiotik untuk membedah pesan/makna yang terkandung dalam 14 meme ibu-ibu naik motor yang hits dimedia sosial dengan menggunakan model segi tiga makna Charles Saunders Pierce, yaitu: tanda (Sign), objek (object) dan interpretasi (interpretant).
\end{abstract}


Hasil penelitian menyimpulkan ada hubungan yang erat antara tanda, obyek dan penafsiran mengenai meme ibuibu naik motor di media sosial.

Kata kunci: meme, ibu-ibu, media sosial, analisis semiotik

\begin{abstract}
The high utilization of the internet and social media resulted in the emergence of the phenomenon of creativity of netizens creating various parody images (memes) to express feelings, conditions and criticize a phenomenon. Meme has opened up new avenues to combine elements such as creativity, art, message and humor into Internet culture. One of the phenomena of memes mother ride motorcycles emphasizes elements that tend hyperrealitas parody, hyperbole and repetition so that these cases interesting and worthy of further investigation because the media is not a channel that is free, he is also the subject of constructing reality, complete with a view, bias, and its preference. This research uses semiotic analysis method to dissect the messages/ meanings contained in the 14 memes of mothers on motorcycles that hits the social dimension using the triangular model of Charles Saunders Pierce meaning: Sign, object and interpretation. The results conclude that there is a close relationship between the signs, objects and interpretations of memes of mothers on motorcycles in social media.
\end{abstract}

Keywords: meme, mothers, social media, semiotic analysis 


\section{A. Pendahuluan}

Keberadaan internet sebagai media baru (new media) memiliki peran yang sangat strategis dalam era komunikasi interaktif. Menurut APJII Pengguna internet di Indonesia saat ini berjumlah 132,7 juta atau $52 \%$ dari jumlah total populasinya. Sebanyak 129,2 juta memiliki akun media sosial yang aktif dan rata-rata netizen menghabiskan waktu sekitar 3 jam per hari untuk mengkonsumsi internet (APJII, 2016). Penggunaan media sosial di media baru sangat populer dan menjadi tren baru dalam masyarakat. Fenomena ini jelas merupakan bukti nyata perkembangan desa global di dunia, terutama di Indonesia. Keunggulan media sosial adalah desainnya yang multi-platform, yaitu dapat diakses dan terhubung di berbagai perangkat digital. Hal ini terlihat dari survei yang pernah dilakukan oleh APJII bekerja sama dengan PusaKaKom Universitas Indonesia yang mensurvei 7.000 pengguna internet dari berbagai provinsi di Indonesia. Hasil survey ini menyebutkan bahwa sebanyak $87,4 \%$ dari total responden mengaku gemar mengakses media sosial (Prihadi, 2015).

Kehadiran media baru terus ditunjang dengan kemajuan teknologi komunikasi yang membuat proses interaksi sosial masyarakat mengalami perubahan yang signifikan. Komunikasi merupakan salah satu proses sosial yang sangat mendasar dan vital dalam kehidupan manusia. Melalui komunikasi, manusia dapat saling bertukar pesan dan informasi. Dengan kemajuan teknologi yang ada saat ini, manusia diberikan pilihan cara berkomunikasi yang lebih beragam lagi. Apabila manusia awalnya hanya bisa berkomunikasi secara verbal dan nonverbal, kini dengan adanya internet manusia juga dapat melakukan komunikasi secara visual, misalnya komunikasi yang semakin beragam melalui media sosial seperti facebook, twitter, instagram. Perkembangan teknologi dalam berkomunikasi secara visual adalah sebuah keniscayaan. Salah satu bukti nyata masifikasi perkembangannya adalah hadirnya internet. Internet atau Interconnection-networking merupakan seluruh jaringan komputer yang saling terhubung dengan menggunakan Standard system global transmission control protocol/Internet protocol suit (TCP/IP) sebagai protokol pertukaran paket untuk melayani miliaran pengguna internet di seluruh dunia. 
Geliat permainan-permainan visual yang menjadi konsumsi masyarakat virtual hari ini terjadi secara masif. Berbagai visualisasi gambar setiap hari hadir di berbagai media baru seperti gambar mengenai kehidupan perempuan. Dewasa ini, tema mengenai perempuan sudah semakin banyak dimunculkan di media massa. Berbicara mengenai perempuan di media tentu tak bisa dilepaskan dari permasalahan gender (Littlejohn, 2009). Gender menjadi salah satu isu yang menarik dalam isi media. Dari tahun ke tahun, terdapat tren yang berbeda mengenai bagaimana gender direpresentasikan di media. Seiring dengan makin tingginya pemanfaatan internet dan media sosial oleh masyarakat Indonesia, melahirkan fenomena baru dikalangan penggunanya yaitu kreativitas pembuatan meme yang kemudian dengan cepatnya tersebar dan dikomentari di media sosial. Meme diartikan sebagai ide, perilaku atau gaya yang menyebar dari satu orang ke orang lain. Meme di internet mengambil bentuknya dalam sebuah gambar, hyperlink, video, website, atau hashtag. Meme beredar di jejaring sosial dari satu teman ke teman lainnya. Meme menjadi populer karena bisa menjadi bahan lelucon, sindiran, ekspresi perasaan pengguna di dunia maya dan hal ini dengan cepat menjadi populer dan mewabah (Luthfi, 2015).

Selain itu, banyak juga kreator yang sengaja membuat meme untuk tujuan menyudutkan pihak-pihak tertentu, apalagi jika pihak tersebut membuat kesalahan. Dipastikan para pembuat meme secara berjamaah menjadikan mereka candaan buruk melalui meme-meme yang beredar luas dan cepat melalui media sosial,berbagai ekspresi perasaan pun menjadi sasaran empuk para pembuat meme seperti memememe kasus Haji Lulung (Juditha, 2015). Tidak hanya ekspresi bahagia, namun juga kesedihan. Sebagai bentuk komunikasi, muatan inforamasi meme memang tidak jarang dijadikan wadah untuk perang wacana oleh banyak orang yang berkepentingan. Mungkin tujuan para kreator adalah menjadikannya humor parodi dan hanya untuk hiburan semata. Namun mereka tidak mempertimbangkan efek lainnya setelah mereka menyebarkannya secara massif di media sosial yang dapat di akses secara global. 
Memasuki Tahun 2014 sejak kehadiran motor matik,para perempuan semakin melirik mode transportasi roda dua. Apalagi desain motor matik semakin cantik sehingga mereka tidak hanya lebih fleksibel berkendara, namun juga tetap mampu tampil gaya.Namun safety riding haruslah menjadi perhatian utama pengendara motor perempuan Indonesia. Data Direktorat Lalu Lintas Polda Metro Jaya, 2014 menyebutkan bahwa peningkatan sebesar 49,5\% pada kecelakaan sepeda motor di Indonesia melibatkan perempuan. Berdasarkan sumber data Korlantas periode 2014 -2015, perbandingan tingkat kecelakaan antara perempuan dan laki-laki sebesar 5:2. Hal ini terjadi karena terdapat banyak pengendara motor perempuan yang kurang memahami aturan berlalu lintas dan bagaimana mengendarai motor sesuai aturan lalu lintas. Fenomena ini juga menggugah para pembuat meme untuk membuat edisi khusus ibu-ibu sebagai ratu jalanan dan menjadi sosok yang paling ditakuti di jalan raya yang menjadi viral di media sosial, mulai dari tidak menggunakan helm, kemudian dalam berkendara motor lupa menghidupkan atau mematikan lampu sign sehingga kerap berbelok begitu saja. Selain itu, meme ibu-ibu yang suka jalan di tengah dengan laju berkendara yang pelan sehingga menyulitkan pengendara motor atau mobil di belakangnya. Inilah alasan yang membuat pengguna internet (netizen) membuat atau menyebarkan sindiran melalui meme-meme yang diciptakan para kreatornya.

Fenomena ini menjadi menarik untuk diteliti karena disamping menjadi kasus hangat dan booming di media sosial, kasus ini juga sempat menjadi trending topic di media sosial sebagai kasus yang paling banyak mendapat perhatian dari pengguna media sosial, seperti meme yang sempat fenomenal di jejaring sosial Facebook. Media sosial menampilkan sosok ibu-ibu yang naik motor sebagai sebuah ancaman, ini dapat membawa citra buruk bagi ibu-ibu pengendara motor. Secara langsung maupun tidak meme tersebut telah menyudutkan ibu-ibu yang mengendarai motor di jalan raya karena dianggap sebagai ancaman bagi pengendara yang lain, padahal tidak semua ibu-ibu pengendara motor berperilaku seperti yang digambarkan di dalam meme. Perilaku beberapa pengemudi perempuan dijadikan parodi meme yang cenderung hiperbola (melebih-lebihkan) dan repetisi/alterasi (mengulang-ulangi) contohnya seperti meme hal seperti itu tidak akan menyelesaikan masalah, 
Selain itu juga agar lebih sadar diri bahwa jalan raya itu bukan milik pribadi. Menurut Lippman (2007) citra adalah gambaran tentang realitas dan tidak harus sesuai dengan realitas. Citra adalah dunia menurut persepsi seseorang. Lippman menyebutnya dengan " the picture in our head". Citra terbentuk dari informasi yang diterima. Realitas yang ditampilkan oleh media adalah realitasyang sudah diseleksi atau realitas tangan kedua (second hand reality). Masyarakat akhirnya membentuk citra mengenai lingkungan sosial atau individu berdasarkan realitas yang dijabarkan oleh media massa. Hal ini sejalan dengan pernyataan pandangan konstruksionis, media bukanlah sebuah saluran yang bebas, ia juga subjek yang mengonstruksi realitas,lengkap dengan pandangan, bias, dan pemihakannya. (Burton, 2010). Disini media berperan sebagai agen konstruksi sosial yang mendefinisikan realita. Media melakukan konstruksinya dengan cara memilih realitas mana yang diambil dan mana yang tidak. Dengan demikian, konstruksi yang dibentuk oleh media sosial akan ditangkap oleh masyarakat sebagai citra yang sebenarnya termasuk dalam mengonstruksi citra perempuan.

Beredar luasnya meme perempuan bertemakanibu-ibu naik motor di media sosial lebih menekankan unsur parodi, cenderung hyperrealitas, hiperbola dan repetisi/alterasi menunjukkan bahwa kasus ini menarik dan layak diteliti lebih lanjut. Karena itu berdasarkan latar belakang di atas memunculkan rumusan masalah dalam penelitian ini yaitu bagaimana kontruksi perempuan dimedia sosial dalam analisis semiotik Charles Saunders Pierce?. Tujuan dari penelitian ini adalah untuk mendapatkan gambaran tentang makna sosial meme perempuan bertema ibu-ibu naik motor yang beredar menjadi viral media sosial.Penelitian ini juga diharapkan dapat memberikan kontribusi terhadap pengembangan ilmu pengetahuan terutama ilmu komunikasi dan media. Diharapkan juga memberikan kontribusi terhadap masyarakat khususnya bagi pengguna internet untuk menggunakan media sosial secara kritis dan bijak. Meskipun parodi meme merupakan fenomena baru di media sosial, namun kajian dan penelitian tentangnya 
sudah banyak dilakukan. Seperti penelitian yang dilakukan oleh Wella, dengan judul "Pengaruh Ilustrasi Visual Meme "Rage Face" Terhadap Frekuensi Kunjungan Website 9GAG"(Wella, 2013). Dengan mengusung metode kuantitatif untuk menguji hipotesa penulis, penelitian ini menghasilkan pernyataan Rage Face hanya berpengaruh pada kunjungan awal saja tetapi tidak pada kunjungan-kunjungan berikutnya. Penelitian ini lebih bersifat eksperimental dengan menguji hubungan penggunaan salah satu varian meme terhadap ketertarikan pengunjung terhadap situs hiburan. Selanjutnya Abdul Aziz Turhan Kariko sebelumnya telah melakukan studi dengan judul Humorous Writing Exercise Using Internet Memes On English Classes. Abdul Aziz dalam penelitian ini membahas tentang penemuan meme oleh pengguna internet dan mencoba menggali mengapa meme dianggap menarik bagimereka dan berusaha mendekonstruksi apa itu internet meme dan apa efek yang dihasilkannya, terutama pada bagaimanahubungan antara gambar, teks, dan makna yang terhubung satu sama lain untuk membentuk pesan sosial, politik, emosi publik, atau sekedar membuat humoryang menghibur (Kariko, 2012).

Penelitian lain juga dilakukan oleh Paul (2009) tentang "Meme Maps: A Tool for Configuring Memes in Time and Space” Penelitian ini menyajikan sebuah metode elegan untuk visualisasi meme yang juga merupakan transmisi budaya. Hasil penelitian ini juga menyebutkan bahwa meme merupakan alat yang ampuh dan fleksibel untuk menangkap, menampilkan berbagi informasi yang dapat menembus ruang dan waktu, serta mudah dipelajari dan diterapkan. Penelitianpenelitian di atas kebanyakan membahas mengenai meme dari sisi psikologi dan transmisi budaya dengan metode eksperimen, positivistic dan kualitatif. Sehingga letak perbedaannya dengan penelitian ini sangatlah jelas sekali. Selain terletak pada perbedaan kasus yang dibahas, penelitian ini juga yang mencoba menggali penanda dan petanda didalam sebuah pesan yang berbeda dengan kualitatif yangberusaha menggali makna dibalik pesan melalui analisis semiotik meme perempuan bertema ibu-ibu naik motor di media sosial. Kasus meme ibu-ibu naik motor yang fenomenal dan menjadi trending topic di media sosial. Penelitian dengan topic ini sebelumnya belum pernah diteliti, karena itu penelitian ini dianggap penting untuk dilakukan. 
Istilah meme berasal dari bahasa Yunani kuno yaitu "mimeme" yang berarti sesuatu yang meniru atau menyerupai (Dawkins, 1989). Istilah lain yang sama yaitu "meme" yang berarti memori. Meme dapat beraplikasi dengan sendirinya (dalam bentuk peniruan) dan membentuk suatu budaya, cara seperti ini mirip dengan penyebaran virus (tetapidalam hal ini terjadi di ranah budaya). Sebagai unit terkecil dari evolusi budaya, dalam beberapa sudut pandang meme serupa dengen gen. Dawkins (2006), menceritakan apa dan bagaimana dia menggunakan istilah meme untuk menceritakan bagaimana prinsip darwinian untuk menjelaskan penyebaran ide ataupun fenomena budaya. Dawkins juga memberi contoh meme yaitu nada, kaitan dari susunan kata, kepercayaan, gaya berpakaian dan perkembangan teknologi. Teori meme menjelaskan bahwa meme berkembang dengan cara seleksialam (mirip dengan prinsip evolusi biologi yang dijelaskan oleh penganut Darwinian) melalui proses variasi, mutasi, kompetisi, dan warisan budaya yang mana mempengaruhi kesuksesan reproduksi di setiap individu. Maka dengan demikian meme, menyebar berupa ide dan bila tidak berhasil akan mati, sedangkan yang lain akan bertahan, menyebar, dan (untuk tujuan yang lebih baik bahkan lebih buruk) akan bermutasi. "Ilmuwan memetika mempunyai pendapat bahwa meme yang mempunyai ketahanan terbaik akan menyebar dengan efektif dan mempengaruhi si objek (suatu individu)".

Meme yang dimaksud disini adalah meme yang berkembang di dalam internet. Berbentuk berupa gambar adegan sebuah film, anime, ilustrasi dsb, disebarkan melalui website, blog, sosial media, juga di beberapa media massa yanglain. Tujuan penggunaan meme inipun sangat beragam, diantaranya digunakan untuk menceritakan pengalaman pribadi, parodi dari sebuah kejadian, mengolok-olok, nasehat, kritik dll yang sangat bergantung pada kode-kode kultural dimana meme itu tersebar. Pada tahun 2013, Richard Dawkins menjelaskan bahwa internet meme merupakan murni sebuah penciptaan dari kreativitas manusia, biaspula diartikan sebagai "pembajakan sebuah ide" yang berkembang kearah yang baru. Internet meme meninggalkan sebuah jejak sejarah pada media massa tidak seperti meme yang lainnya yang membuat mereka mampu untuk dianalisa. 
Untuk mengungkap makna atau pesan tersembunyi yang dibawa oleh meme, pemaknaan secara konotatif tentu saja menjadi kunci akan hal ini. Karena itu, peneliti menggunakan analisis semiotika sebagai alat analisis untuk menjelaskan pesan/makna yang terkandung dalam sebuah meme dengan menggunakan model segi tiga makna Charles Sanders Pierce, yaitu: tanda (sign), objek (object) dan interpretasi (interpretant). Menurut Peirce dalam Budiman (2004:25), sebuah tanda adalah sesuatu yang bagi seseorang mewakili sesuatu atau yang lain dalam beberapa hal/kapasitas. Sesuatu yang lain itu dinamakan sebagai interpretant (interpretasi) dari tanda yang pertama- pada gilirannya mengacu pada object (objek). Atas dasar ini Pierce mengadakan klasifikasi tanda melalui hubungan segitiga yang dikenal sebagai teori segitiga makna (triangle meaning theory).

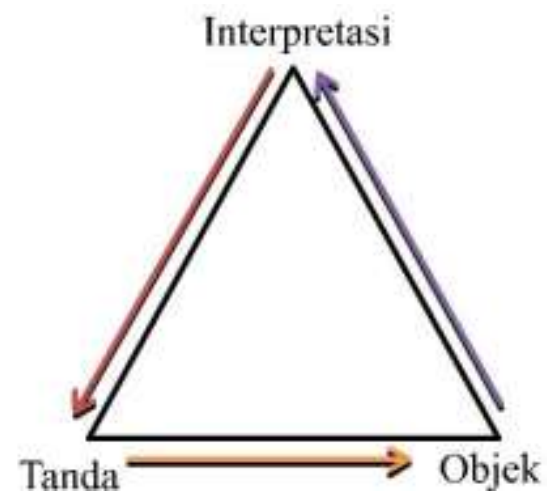

\section{Gambar 1. Tipologi Tanda}

Sumber : John Fiske, Cultural and Communication Studies.

Sebuah tanda mengacu pada sesuatu diluar dirinya sendiri objek, dan ini dipahami oleh seseorang dan ini memiliki efek di benak penggunanya/Interpretant. Kita mesti menyadari bahwa interpretant bukanlah pengguna tanda, namun Pierce menyebutnya dimana-mana sebagai "efek pertandaan yang tepat": yaitu konsep mental yang dihasilkan baik oleh tanda maupun pengalaman pengguna terhadap objek. Interpretant kata (tanda dalam setiap konteks akan menghasilkan pengalaman pengguna atas kata itu dan dia tak akan menerapkannya pada 
sebuah kolase teknik), dan pengalamannya dengan institusi yang bernama "sekolah" sebagai objeknya. Jadi makna itu tidak tetap, dirumuskan kamus, namun bisa beragam dalam batas-batas sesuai dengan pengalaman penggunanya. Batasan itu ditetapkan oleh konvensi sosial; variasi di dalamnya memungkinkan adanya perbedaan sosial dan psikologis di antara penggunanya. (Fiske,1990). Pierce membagi tanda atas icon (ikon), index (indeks), dan symbol(simbol). Ikon adalah tanda yang hubungan antara signifier dan signified bersifat bersamaan bentuk alamiah. Atau dengan kata lain, ikon adalah hubungan antara tanda dan objek atau acuan yang bersifat kemiripan. Indeks adalah tanda yang menunjukkan adanya hubungan alamiah antara signifier dan signified yang bersifat kausal atau hubungan sebab akibat, atau tanda yang langsung mengacu pada kenyataan. Tanda dapat pula mengacu ke denotatum melalui konvensi. Tanda seperti itu adalah tanda konvensional yang biasa juga disebut simbol, jadi simbol adalah anda yang menunjukkan hubungan alamiah antara signifier dan signified. Hubungan ini berdasarkan konvensi (kesepakatan) masyarakat (Sobur, 2004: 41).

Menurut Eco (2009), tanda tidak hanya dibicarakan dalam relasi, kode, dan maknanya, tetapi dalam produk dan produktivitas tanda. Eco menggunakan istilah merujuk pada proses penciptaan, konstruksi dan relasi tanda di dalam dunia kehidupan sosial yang nyata. Produksi dalam semiotika menunjuk pada proses penuturan (uterance), yang perluasan semantiknya tidak hanya berarti penuturan lisan, tetapi juga penuturan dalam pengertian gambar (image) atau benda-benda. Media online sebagai media baru dengan konsekuensi berkembangnya teknologi informasi komunikasi menyebabkan kemudahan meme memproduksi dirinya. Meme mereproduksi dirinya dengan salinan (replica), kembaran (doubles), duplikat, ikonisme, atau keserupaan (similitude). Media online merupakan ruang paling efektif dan efesien bagi meme untuk tumbuh dan membiak. Prinsip meme bahwa ia selalu mencari jaringan sel yang subur tempat ia membiak. Media online ini, serupa dengan jaringan sel yang subur itu, tempat informasi kultural dengan cepat menyebar dan berkembang menjadi wacana komunitas jejaring, Pilliang, (2010:382). 
Meme dikatakan hidup karena kemampuannya secara aktif mengendalikan dan membentuk pikiran manusia dalam rangka keberlanjutannya. Meme mengkopi dirinya sendiri (replication), segera setelah ia menemukan kesempatannya di dalam pikiran manusia, yang memaksa setiap orang untuk mengikuti segala efek, permintaan, bujukan, rayuan, dan suruhannya, yang seseringkali menuju kearah yang tidak diinginkan. Meme semiotik bersaing dalam menarik perhatian manusia. Tanda, citra atau simbol baru menguasai pikiran manusia, mengalahkan yang sudah tua, oleh karena ia lebih menarik, lebih kuat, lebih bergaya, lebih efisien, lebih sensual, atau lebih murah. Dalam Facebook dan semua sosial media lainnya merupakan ruang semio-memetic itu, dengan tanda-tanda (ucapan, pandangan, komentar, opini, keluhan, kritikan,gambar, foto) membiak melalui proses replikasi semiotik, dengan tools viral social media (Copy, Cut, Paste, send to, repost, personal mesagge, dan tools viral lainnya), Pillang, (2010:383).

Sebuah realitas sosial tidak berdiri sendiri tanpa kehadiran individu, baik didalam maupun di luar realitas tersebut. Realitas sosial itu memiliki makna ketika realitas dikonstruksi dan dimaknai secara subyektif oleh individu lain, (Astuti, 2017) sehingga memantapkan realitas itu secara obyektif. Individu mengonstruksi realitas sosial dan mengonstruksikannya dalam dunia realitas, memantapkan realitas itu berdasarkan subyektifitas individu lain dalam ini stitusi sosialnya. Maka dari itu realitas didefinisikan sebagai hasil dari konstruksi sosial dalam proses komunikasi tertentu. Membahas tentang teori konstruksi sosial (social construction), tentu tidak lepas perannya dari teoritik yang dikemukakan oleh Peter L. Barger dan Thomas Luckman. Berawal dari istilah konstruktivisme, konstrksi realitas sosial terkenal sejak diperkenalkan oleh Peter L. Barger danThomas Luckman pada tahun 1966 melalui bukunya "the social construction ofreality: A tretise in the sociological of knowledge" menjelaskan bahwa realitas sosial dikonstruksi melalui proses eksternalisasi, objektifitas, dan internalisasi. Konstruksi sosial tidak berlangsung dalam ruang hampa namun syarat akan kepentingan-kepentingan. Bagi kaum konstruktivitisme, realitas hadir dalam keadaan subyektif. Realitas akan tercipta melalui 
berita tidak dapat disamakan sebagai cerminan realitas, tetapi ia harus dipandang sebagai konstruksiatas realitas.

Pada kenyataannya, realitas sosial itu berdiri sendiri tanpa adanya individu baik di dalam maupun di luar realitas tersebut. (Astuti, 2015). Realitas memiliki makna, bila realitas sosial dikonstruksi dan dimaknai secara subyektif oleh individu lain sehingga memantapkan realitas itu secara obyektif. Individu mengonstruksi realitas sosial dalam dunia nyata (realitas) berdasarkan subyektivitas individu lain dalam institusi sosialnya. Melalui konstruksi sosial media, dapat dijelaskan bagaimana media massa membuat gambaran tentang realitas. Untuk itu, peneliti menggunakan paradigma ini sebagai pandangan dasar untuk melihat bagaimana media sosial memaknai, memahami dan kemudian membingkai citra perempuan kedalam bentuk parodi meme ibu-ibu naik motor.

Penelitian ini mencari kontruksi makna sosial yang terkandung dalam beberapa meme Ibu-Ibu naik motor yang hits di media sosial dengan melihat hubungan yang ada pada tanda, objek dan penafsiran. Tanda adalah gambar, rupa, bentuk, warna pada meme-meme perempuan bertema Ibu-Ibu naik motor. Sementara unsur objek adalah makna dari tanda-tanda yang ada pada meme Ibu-Ibu naik motor, sedangkan penafsirnya adalah sikap dan pola pemikiran para kreator meme Ibu-Ibu naik motor atau pun orang yang menggunakan tanda dengan menggunakan metode analisis semiotik dengan pendekatan kualitatif. Penelitian semiotik adalah metode untuk menganalisis dan memberikan makna-makna terhadap lambang-lambang pesan atau teks (Pawito, 2007). Dalam penelitian ini, sebagai pisau analisis digunakan analisis semiotik dari Pierce yang menekankan 3 unsur utama yaitu tanda, obyek, dan penafsir. Sehingga yang dikaji dalam penelitian ini adalah Tanda (gambar, rupa, bentuk, warna pada meme-meme Ibu-Ibu naik motor); Objek (makna dari tanda-tanda yangada pada meme IbuIbu naik motor); Penafsir (sikap dan pola pemikiran para kreator meme Ibu-Ibu naik motor atau orang yang menggunakan tanda). Adapun teknik pengumpulan data dalam penelitian ini terbagi dua bagian. Data primer adalah pengumpulan sejumlah meme tentang Ibu-Ibu naik motor.

Ketiga media sosial ini sengaja dipilih karena paling banyak mengedarkan meme tentang Ibu-Ibu naik motor. keselurahan meme hits 
tentang Ibu-Ibu naik motoryang beredar di media sosial pada minggu pertama dan kedua November 2016. Ada 14 meme yang diambil secara kebetulan dalam penelitian ini dengan pertimbangan mengambil parodi meme paling hits di media sosial. Sementara data sekunder diperoleh dari berbagai kajian dan literatur yang berhubungan dengan permasalahan yang dibahas seperti dari buku teks, media massa dan internet. Data primer yang diperoleh hasil penelitian ini kemudian disesuaikan berdasarkan kebutuhan penelitian. Selanjutnya dilakukan pengolahan data dan dianalisis secara deskriptif dengan menjelaskan, menguraikan dan membandingkan informasi yang diperoleh dengan teori serta konsep-konsep yangsudah tetapkan serta hasil-hasil penelitian sebelumnya untuk memperkaya pembahasan hasil penelitian (triangulasi).

\section{B. Pembahasan}

Fenomena ibu-ibu yang sering salah dalam menggunakan lampu sen dijalan raya akhir-akhir ini menjadi pembicaraan dalam masyarakat khususnya masyarakat dalam dunia maya (warganet). Semakin banyaknya ibu-ibu yang naik motor di jalan berkaitan erat dengan kemudahan kredit sepeda motor, walaupun pemerintah sudah membuat aturan minimal uang muka 30\%, namun perusahaan leasing memudahkannya dengan memberikan uang muka yang murah. Ditambah lagi dengan makin mudahnya mengendarai sepeda motor matic. Menurut pendapat beberapa warganet di media sosial menyebutkan bahwa mereka pernah beberapa kali menemukan kejadian ibu-ibu yang berkendara secara tidak tertib. Akibatnya para warganet ramai-ramai menjadikan ibu-ibu sebagai bulan-bulanan di media sosial. Selain melakukan postingan-postingan yang menyindir ibu-ibu naik motor, para warganet juga berkreasi membuat meme-meme lucu. Peredaran meme-meme ini sangat luas di media sosial dan terjadi begitu cepat sehingga membuat ibu-ibu menjadi trending topic hangat yang hilir mudik beredar di media sosial. Penelitian ini mencari makna sosial yang terkandung dalam beberapa meme Ibu-Ibu naik motor yang tenar di media sosial dengan menggunakan model segi tiga makna Pierce, yaitu: tanda (sign), objek (object) dan penafsiran (interpretant) untuk mencari hubungan diantaranya. 


\section{Tanda}

Bahasan pertama adalah mengenai "Tanda". Tanda dalam penelitian semiotik adalah gambar, rupa, bentuk dan warna yang ada dalam item kajian yaitu dua belas (12) gambar meme tentang ibu-ibu naik motor yang menjadi bahan kajian.

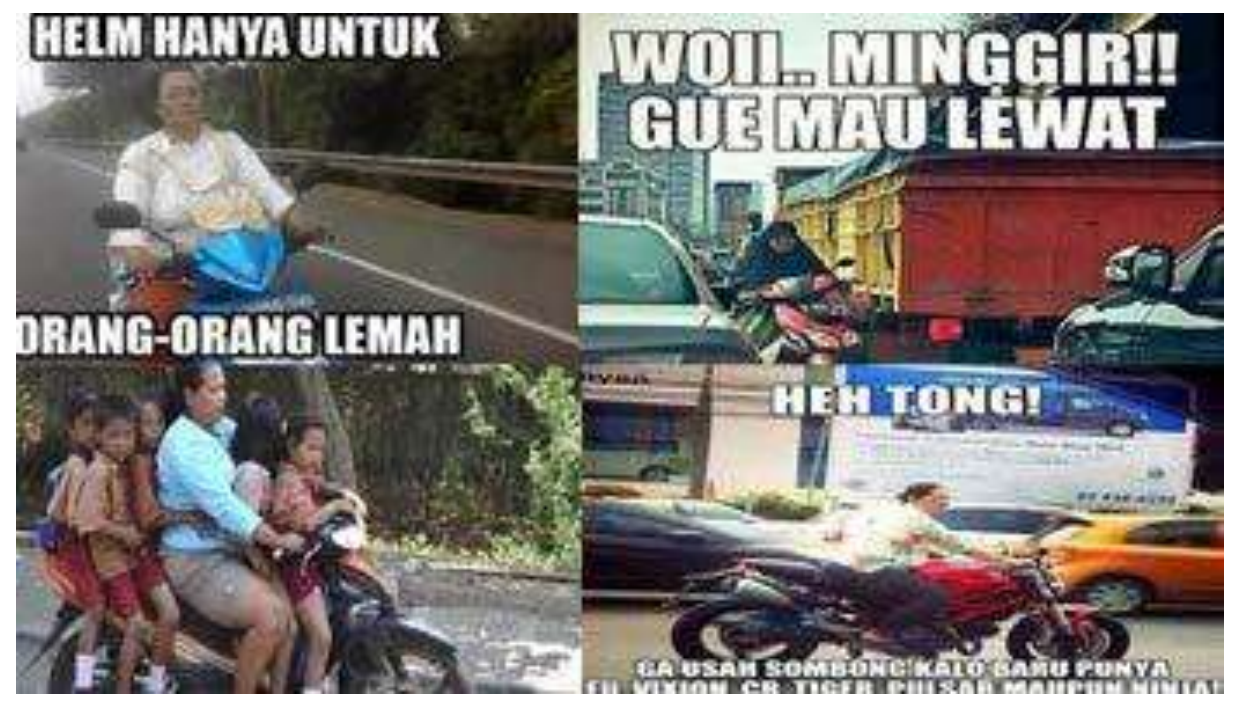

Gambar 2.

Tanda (gambar, bentuk, rupa) beberapa Meme Ibu-ibu naik motor (Sumber: Facebook, Twitter dan Instagram)

Bentuk dari berbagai meme ini rata-rata hampir menunjukkan karakter yang sama, yaitu berupa foto dan komik yang berbentuk empat persegi panjang, dan ada pula yang berbentuk bujursangkar. Namun dari beberapa bentuk ada juga gambar-gambar yang digabung menjadi satu kemudian diberi keterangan gambar di dalamnya. Ada pula gambar yang berdiri sendiri dengan komentar- komentar satire di dalamnya, serta gambar yang dijadikan komik dengan komentar-komentar selayaknya lembaran buku komik, sementara penggunaan permainan warna dalam meme-meme ini dapat dikatakan masih standar, sama saja dengan gambar-gambar lainnya yang biasanya diposting pada media sosial. Kebanyakan menggunakan warna asli dari foto yang digunakan. Namun untuk gambar-gambar yang dibuat dalam bentuk meme komik, warna-warna yang digunakan cenderung berwarna hitam-putih dan warna dasar dari foto aslinya. 


\section{Objek.}

Bahasan kedua mengenai objek. Objek dalam semiotik adalah makna dari tanda-tanda yang ada pada gambar. Makna-makna yang terkandung dalam sejumlah meme ibu-ibu naik motor adalah kebanyakan berisi sindiran pada karakter dan tingkah laku ibu-ibu selama menggunakan motor dijalan umum. Para kreator meme Ibu-ibu naik motor banyak memaknai gambar pada sosok ini sebagai sosok yang unik, tidak taat aturan, preman jalanan, penyebar terror, selalu benar dan tidak konsisten dalam berkendaraan dijalan umum.

Objek pertama pada meme menceritakan sosok ibu-ibu naik motor digambarkan sebagai pribadi yang tidak konsisten dengan pilihannya sendiri, ini diperlihatkan melalui beberapa meme yang berseliweran di berbagai jenis media sosial, dimana saat ibu-ibu naik motor di jalanan umum cenderung tidak konsisten dalam hal menggunakan lampu tanda kendaraan (lampu sein). Dalam meme-meme tersebut mereka digambarkan memilih menghidupkan sein kekiri namun beloknya ke kanan dengan komen sindiran "namanya juga ibu$i b u$ ". Begitu pula dengan sebuah meme lainya yang dibuat dalam bentuk potongan komik hitam-putih yang menceritakan seorang ibu yang dengan sengaja menghidupkan lampu motor sein kanan sebagai sebuah pertanda agar kendaraan-kendaraan yang berada dibelakang motornya untuk berbelok ke kanan atau ke arah lainnya, sebab motor yang dikendarainya akan belok ke kiri. Melalui meme ini para kreator mengisyaratkan bahwa ibu-ibu pengendara motor tidak paham akan fungsi lampu sein yang ada di motor.
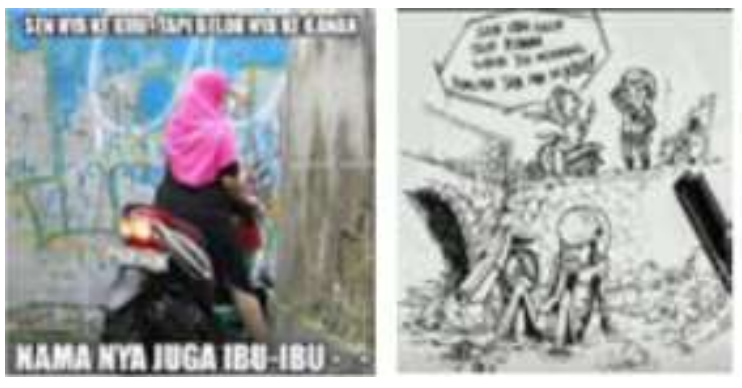

\section{Gambar 3}

Objek (makna) beberapa Meme Ibu-ibu Naik Motor

(Sumber: Facebook, Twitter dan Instagram) 
Beberapa kreator meme-meme juga ada yang menganalogikan ibu-ibu naik motor dengan preman jalanan. Hal ini dimaknai karena terdapat banyak fenomena ibu-ibu yang melanggar aturan ketika menggunakan jalan umum seperti mengendarai motor dijalan raya dengan melawan arus kendaraan lainnya dengan komen "Jalan Aing Kumaha Aing” (bahasa Sunda pasaran) yang artinya "jalan Aku terserah aku". Meme lainnya juga menggambarkan seorang ibu yang mengendarai motor dengan gaya acrobat seperti perilaku preman jalanan dengan memakai komentar "ra usah dipiker jempingke wae" (bahasa Jawa) yang artinya "Nggak usah dipikirin jempingin aja motornya". Kemudian pada meme sindiran selanjutnya digambarkan seorang ibu-ibu yang tengah mengendarai motor gede (moge) atau yang sering dikenal sebagai motornya kaum adam dengan komentar " heh tong, ga usah sombong kalo baru ponya Vixion, Tiger, Pulsar maupun Ninja". Ketiga gambar tersebut merepresentasikan bahwa ibu-ibu menjadi preman di jalan raya.
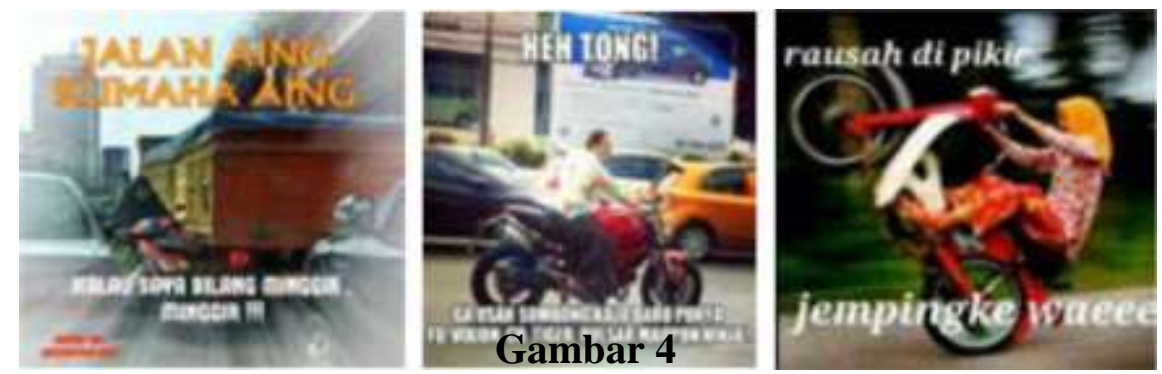

Objek (makna) beberapa Meme Ibu-ibu Naik Motor

(Sumber: Facebook, Twitter dan Path)

Meme-meme di media sosial yang diproduksi oleh para kreator dimaknai adanya perasaan sentimental dan ketidaksukaan warganet terhadap sosok ini. Seperti yang digambarkan dalam sebuah meme dimana ada terdapat ibu-ibu yang naik motor maka dihimbau untuk segera menjauhi mereka dengan komentar bahwa "kalo jumpa yang beginian lebih baik putar arah dari pada dapat masalah”. Meme lain yang penuh sindiran adalah meme tentang adanya kecelakaan dalam pertandingan lomba balap motor internasional, kemudian komentar dalam meme tersebut mengatakan bahwa penyebab terjadinya 
kecelakaan dalam pertandingan tersebut bukan karena kesalahan mereka namun karena ada ibu-ibu bawa motor di dalam sirkuit dalam komentar "sekali lagi saya tegaskan bukan Rossi yang buat Marquez jatoh, tapi ibu-ibu bawa matic". Komentar bohong kreator dan tanpa bukti otentik menunjukkan sentimen dan tidak suka terhadap perilaku tidak tertib ibu-ibu ketika naik motor di jalan umum.
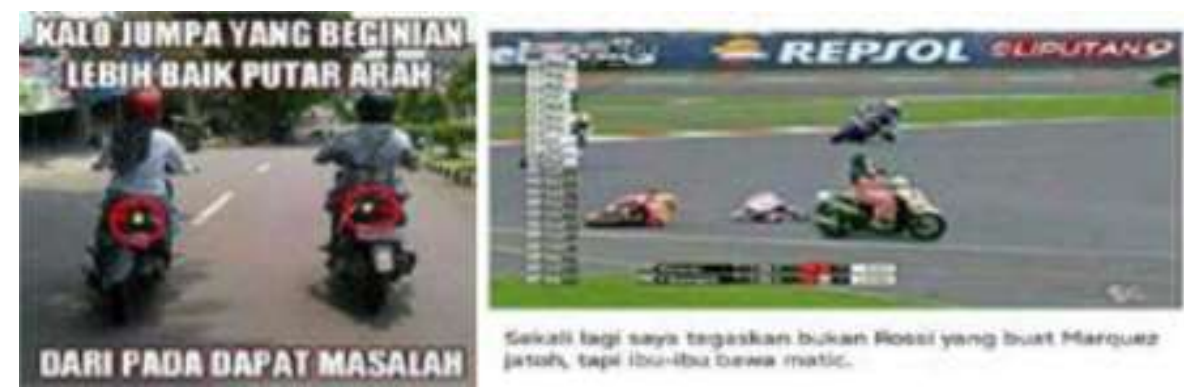

\section{Gambar 5}

Objek (makna) Beberapa Meme Ketidaksukaan Warganet Terhadap Ibuibu Naik Motor

(Sumber: Facebook, Twitter dan Instagram)

Makna berikutnya yang terkandung dalam meme ibu-ibu naik motor ini adalah gambaran ibu-ibu naik motor yang enggan menaati peraturan dalam berlalu lintas di jalanan umum. Pada meme digambarkan seorang ibu yang dengan santainya mengendarai motornya di jalan raya dengan tanpa menggunakan helm. Padahal helm wajib digunakan oleh pengendara lalu lintas, apalagi jika melalui jalan raya. Gambar meme selanjutnya pada kasus yang sama memperlihatkan seorang ibu yang tidak terima ditilang oleh anggota polisi lalu lintas karena si ibu tidak juga menggunakan helm dengan kutipan percakapan, Polisi: " $b u$, $i b u$ saya tilang k?larena ibu naik motor ndak pake helm...Ibu: "nah, elu ngapain pake helm tapi kagak naek motor? Mending tuh helm lu pinjemin ke gua kan? Ribet amat lu tong!". Pada meme-meme ini menggambarkan seorang ibu yang tidak taat pada aturan bahkan memberikan perlawanan terhadap aturan itu sendiri. 

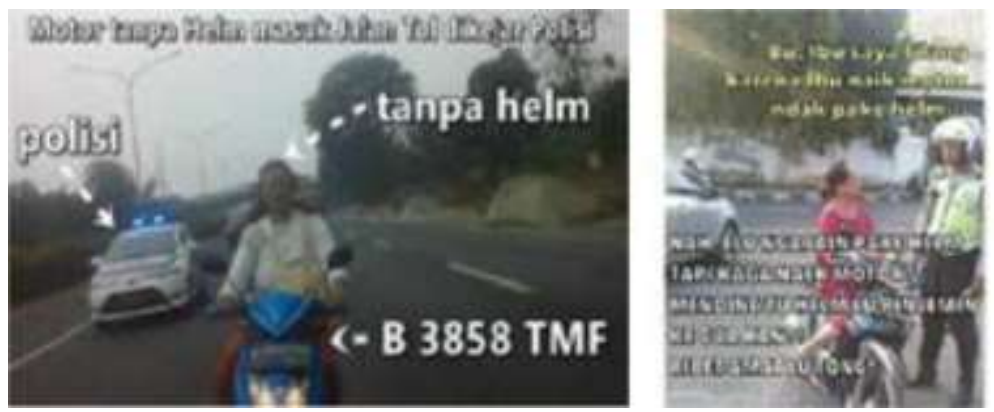

Gambar 6

Objek (makna) Meme Ibu-ibu Naik Motor yang melanggar aturan

(Sumber: Facebook. Twitter dan path)

Meme lain menceritakan ibu-ibu naik motor yang digambarkan menganggap dirinya selalu benar sebagaimana dalam gambar. ada gambar pertama terlihat dua orang ibu-ibu (polisi) menggunakan motor tanpa memakai helm. Meme yang ditampilkan para kreator menyindir aparat hukum yang lalai karena mereka berstatus ibu-ibu naik motor yang digambarkan dalam meme "selalu benar". Dalam gambar tertulis komentar "ibu-ibu bawa motor selalu benar, cewek selalu benar, polisi selalu benar, elu ketemu ibu-ibu polisi bawa motor sambil bonceng polisi cewek kelar idop lo". Pada gambar berikutnya juga memperlihatkan pemaknaan terhadap objek yang sama yaitu ibu-ibu bawa motor yang selalu benar. Dalam gambar memperlihat seorang pria yang memberikan komentar terhadap sebuah peristiwa di jalan raya "yang nabrak dia, yang marah dia juga, ibu-ibu naik motor".

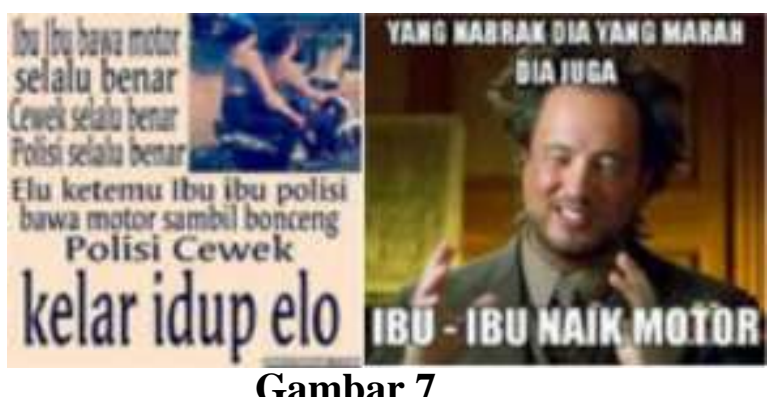

Gambar 7

Objek (makna) Meme Ibu-ibu Naik Motor yang selalu benar

(Sumber: Facebook \& IG)

Makna lain dalam meme menggambarkan ibu-ibu yang digambarkan sebagai penguasa jalan raya. Gambar meme yang berbentuk komik pertama menceritakan seorang pria yang mengendarai motor dengan 
wajah gundah gulana karena menemukan kemacetan di jalan raya. Setelah dia mengetahui penyebab kemacetan dia berkomentar "Njir, pantesan macet, ibu-ibu lagi konvoi ternyata". Meme ini mengandung ungkapan tidak sopan melalui komentar "Njir" yang artinya: anjing". Meme ini juga tidak realistis karena dalam kehidupan nyata hampir tidak pernah terjadi ibu-ibu berkonvoi dijalan raya. Tidak sampai disana saja pada objek meme sindiran selanjutnya menggambarkan kumpulan ibu-ibu yang sedang naik motor kemudian disisipkan komentar "ada 2 penguasa jalanan, 1. Orang lagi touring, 2. Emak-emak. Ada emakemak lagi touring? Kelar idop lo". Bahasa "kelar idop lo" dimaksudkan sebagai ungkapkan "tamatlah riwayatmu". Makna yang sama juga ditemukan pada objek meme tentang remaja perempuan yang berkendara motor dimana dianggap sebagai calon emak-emak penguasa jalanan dengan komentar "ketika "The Power of Emak-Emak"dimulai sejak dini”..
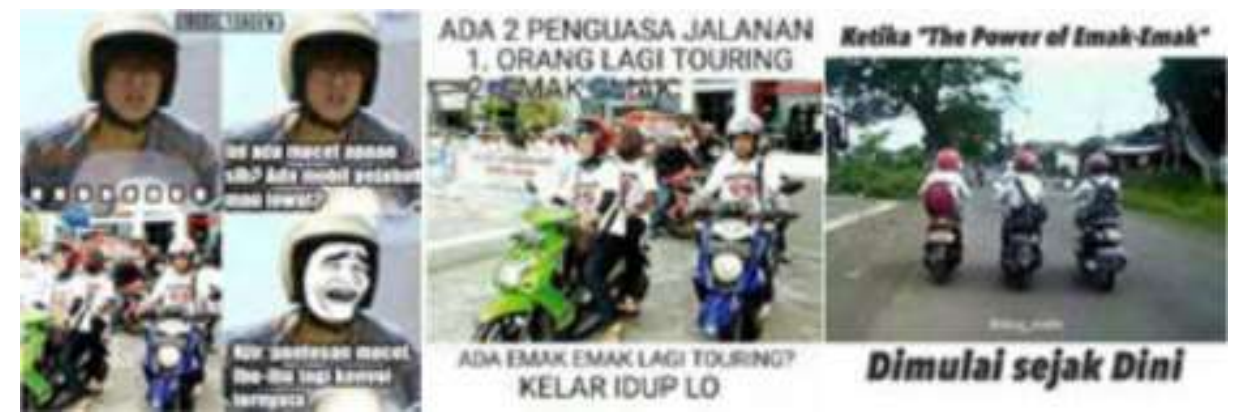

\section{Gambar 8}

Objek (makna) Meme Ibu-ibu Naik Motor yang selalu benar

(Sumber: Facebook dan Twitter)

\section{Interpretant}

Bahasan selanjutnya adalah penafsir (interpretant). Dalam kajian Semiotik, penafsir adalah sikap dan pola pemikiran para kreator meme atau orang yang menggunakan tanda (meme) ibu-ibu naik motor tersebut. Dalam artikel ini terlihat sikap dan pemikiran oleh kreatorkreator meme dan para warganet cenderung beragam meskipun warganet kebanyakan memiliki kesamaan pendapat dan bahkan saling diberikan oleh warganet di media sosial setelah menyaksikan memememe ibu-ibu naik motor. Kebanyakan meme tersebut di-retweet dan 
disiarkan kembali melalui akun media sosial mereka yang lainnya seperti di facebook dan Instagram dan yang tidak ketinggalan di aplikasi messenger mereka yaitu Whatsapp, Black Berry Messenger dan Line. Meskipun begitu tidak sedikit pula warganet yang tidak sepakat. Hal ini terlihat dari beberapa kolom komentar warganet yang tidak mendukung beberapa konten meme para kreator yang disebarkan di media sosial. Dari hasil membaca tanda dan makna meme-meme diatas, penafsiran secara umum warganet mengenai meme ibu-ibu naik motor adalah sosok yang berbahaya dan pantas untuk diwaspadai ketika mengendarai motor.

Artikel ini mengukuhkan hubungan erat antara tanda, objek dan penafsir. Dimana ada kasus yang dinilai oleh para warganet untuk segera ditanggapi yaitu sifat sembrono dari ibu-ibu ketika berkendara sepeda motor menjadi fenomena yang menggundang banyak kritikan warganet. Kebiasaan buruk sebagian ibu dalam berkendara dikritik dengan banyaknya meme yang beredar di media sosial. Ada tanda-tanda yang dibangun dari kreatifitas meme ini. Setiap tanda ini memiliki obyek atau makna-makna yang dibangun berdasarkan tanda-tanda tersebut. Kesemuanya ini dimaknai sama antara para kreator meme dan para penikmat meme ibu-ibu naik motor. Dalam perkembangannya, meme telah membuka jalan baru untuk mengkombinasikan berbagai unsur seperti kreatifitas, seni, pesan dan humor ke dalam budaya internet. Bahwa untuk mengekspresikan perasaan, mereprensatasikan kondisi, dan mengkritisi sebuah fenomena, dapat dituangkan dalam meme. Namun, terkadang ekpresi tersebut melebihi batas kewajaran sehingga menimbulkan dampak yang tidak diinginkan.

Jika dilihat dari perkembangan media baru di Indonesia, maka fenomena meme ibu-ibu naik motor ini kebanyakan mengandung makna satire yang merupakan unsur paduan antara ironi dan sarkasme yang biasanya dikemas dalam bentuk humor. Satire memiliki tujuan dalam mengekspos dan mengritik kesalahan orang, sehingga sebuah satire selalu mempunyai fungsi kritik (Berger, 1997). Oleh karena itu para keator meme ibu-ibu naik motor banyak yang menciptakan satire dalam karya meme mereka. Di dalam meme tersebut dimaknai dengan 
jelas bahwa ada kritikan mendasar terhadap ibu-ibu yang naik motor di jalan raya yang diciptakan secara spontan dan terkadang berlebihan karena kandungannya cenderung menempatkan posisi perempuan sebagai objek yang selalu mengedepankan emosional. Karena memememe ini menjadi viral di media sosial dan instant messaging sehingga membuat warganet yang melihat dan membacanya menafsirkan hal yang sama dengan para kreator.

Banyak meme yang dikontruksi oleh media sosial cenderung hiperealitas dan tidak memperhatikan sopan santun. Perempuan seringkali menjadi korban baik dalam pemberitaan maupun dalam tayangan-tayangan media massa yang tidak sensitif gender. Beberapa asumsi yang dipercaya ikut mempengaruhi hal tersebut adalah karena chain of activities media massa cenderung dikuasai dan didominasi pihak yang tidak peka gender. Aktivitas berantai itu dimulai dari kreator, fotografer, reporter, editor, layouter, kolomnis, dewan redaksi, loper, juga konsumennya. Hal yang sama juga terjadi di media online, bahwa perempuan yang paling dominan ditampilkan daripada laki-laki.

Saat ini eksistensi perempuan di media online memasuki babak baru, dimana stereotip perempuan mengalami perluasan makna, yaitu tidak hanya semata-mata menjadi objek seks ataupun menampilkan stereotipe perempuan yang lemah lembut, keibuan, halus, cantik, lebih cocok untuk bekerja di dalam rumah (mengurus anak, memasak dan membersihkan rumah). Namun melalui meme tersebut di atas perempuan digambarkan juga memiliki sifat yang biasanya melekat pada laki-laki yaitu lebih kuat, gagah dan keras. Namun begitu, stereotip lainnya yang sudah terlanjur melekat dalam diri perempuan juga tetap terlihat dalam meme di media online seperti selalu mengedepankan emosional dan kurang cerdas.

Citra perempuan dalam meme menjadi bukti bahwa media memiliki peran dalam membentuk realitas. Media berfungsi sebagai sarana untuk mengidentifikasikan diri dengan nilai-nilai lain (termasuk yang digambarkan dalam media). Manusia memiliki nilai-nilai hidupnya sendiri yang pada gilirannya akan ia gunakan untuk melihat dunia. Dengan demikian konsumen media dapat mengetahui nilai-nilai lain di luar nilainya (Astuti, 2016). 
Namun ketika manusia melihat nilai-nilai yang diciptakan oleh media, dengan cepatnya utamanya melalui media sosial. Dalam kasus ini meme maka terkadang nilai-nilai pribadi dalam dirinya cenderung mulai dipengaruhi oleh nilai-nilai yang ditawarkan oleh media secara terus menerus. Media membawa nilai-nilai dari seluruh penjuru dunia yang dengan mudah mempengaruhi khalayak. Kreasi meme ibu-ibu naik motor ini telah merebak dapat membuka ruang publik virtual bagi masyarakat. Ruang publik virtual ini menfasilitasi tumbuhnya entitas yang leluasa mengembangkan dialog publik menanggapi isi-isu ketidakadilan, monopoli serta manipulasi negara dan pasar terhadap masyarakat sipil.

Ketika gambar-gambar berupa meme ini tersebar di dunia maya, khususnya media sosial, siapa saja setelah melihatnya dapat membuat kembali dan menyebarkan meme tersebut dengan cara mengunggah foto tersebut. Dan saat meme itu cukup menarik perhatian, setiap penikmat meme dengan leluasa dapat memberikan komentar apa saja terhadap meme tersebut. Meme dibuat sebagai salah satu cara penyuaraan pemikiran, opini, anekdot, dan lain-lain secara anonim dan massal, melalui aturan meme tersendiri yang disepakati oleh masyarakat di duniamaya. Meme tidak digunakan untuk mencari jawaban dari pembaca, namun meme cenderung memancing komentar pembaca. Dalam kasus meme ibu-ibu naik motor hal tersebut pun terjadi. Meme tersebar secara massif dan tanpa kesepakatan legal dan terus diciptakan dan dikloning melalui media sosial.

\section{Simpulan}

Artikel ini menyimpulkan bahwa meme ibu-ibu naik motor mengusung unsur 'tanda' atau gambar yang beragam tentang cara berkendara ibu-ibu secara tidak tertib yaitu naik motor dengan gagah berani; emosional, ugal-ugalan, tidak taat aturan dan gambar calon ibuibu yang dianggap sebagai ancaman dalam jalan raya. Bentuk berbagai meme berupa foto dan komik yang disertai komentar-komentar satire (humor) di dalamnya. Warna-warna yang digunakan dalam meme-meme ini standar dan tidak berubah dari warna asli foto. Umumnya memememe ini dimaknai sebagai sindiran, humor dan ketidaksukaan kreator meme terhadap cara berkendara ibu-ibu yang baik dalam batas kewajaran dan kesopanan maupun tidak. Meme dipilih karena 
merupakan medium komunikasi yang dengan bebas digunakan pengguna internet untuk menyatakan pendapat dan mudah menyebar cepat khususnya melalui media sosial. Meme ibu-ibu naik sepeda motor dalam batas-batas tertentu menggambarkan perempuan sebagai objek dominasi pria dalam media massa padahal media diharapkan dapat berkontribusi untuk peningkatan kualitas dan peran perempuan termasuk dalam berkendara. 


\section{DAFTAR PUSTAKA}

Astuti, Yanti, 2016. Media dan Gender (Studi Deskriptif Representasi Stereotipe Perempuan dalam Iklan di Televisi Swasta), Yogyakarta: Jurnal Komunikasi Profetik Prodi Ilmu Komunikasi UIN Sunan Kalijaga

Astuti, Yanti, 2015. Simulasi Realitas Sosial Melalui Media Sosial dan Aplikasi Instant Messaging di Cyberspace, Jurnal Komunikasi Profetik Vol. 08, Yogyakarta: Prodi Ilmu Komunikasi

Astuti, Yanti, 2017. Simulasi Realitas Sosial Melalui New Media Studi pada Mahasiswa Yogyakarta Pengguna Smartphone)", Jurnal Pekommas Vol.2 No.1, Makassar: Kominfo

Berger, P.L, 1997, Redeeming Laughter: Comicdimension of Human Experience. Berlin, Jerman:Walter de Gruyter \& Co.

Burton, G, 2000, Membincangkan Televisi: Sebuah Pengantar kepada Studi Televisi, Yogyakarta: Jalasutra.

Dawkins, R, 1989, “11. Memes :the new replicators”. The Selfish Gene (Edisi kedua). Oxford: Oxford University Press.

Dawkins, R, 2006, The Selfish Gene. New York: Oxford University Press

Eco, Umberto, 2009, Teori Semiotika: Signifikasi Komunikasi, Teori kode, Serta Teori Produksi-Tanda, Terjemahan oleh Inyiak Ridwan Muzir, Yogyakarta: Kreasi Wacana.

Fiske, J, 2011, Cultural and Communications Studies, Sebuah Pengantar Paling Komprehensif. Yogyakarta: Jalasutra.

Kariko, Abdul Aziz Turhan, 2012, Humorous Writing Exercise Using Internet Memes On English Classes. Jakarta: Bina Nusantara Pawito, 2007, Penelitian Komunikasi Kualitatif, Yogyakarta: LKIS John, Little., 2009, Teori Komunikasi. Terjemahan oleh Moh. Yusuf Hamdan. Jakarta : Salemba Humanika. 
Juditha, Christani, 2015. "Meme di Media Sosial: Analisis Semiotik Meme Haji Lulung" dalam Jurnal Pekommas, Vol. 18 No. 2

Luthfi,

A.

Fenomena
$(25$

Februari Meme
2015).

Internet.
Asal

Usul

http://techno.okezone.com/read/2015/02/24/207/1110093/asalusul-fenomena-meme-internet, diakses 1Juli 2017

Paul, J. 2009, “ Meme Maps: A Tool For ConfiguringMemes In Time And Space" dalam European Journal of Scientific Research Vol.31 No.1 (2009), pp. 11-18. Euro Journals Publishing, Inc. Fenner School of Environment and Society,Australian National University Canberra, Australia, http://www.eurojournals.com/ejsr.htm akses 28Agustus2017

Piliang, Yasraf Amir, 2010, Hipersemiotika, Tafsir Cultural Studies Atas Matinya Makna. Yogyakarta: Jalasutra.

Prihadi, S. D, "Berapa Jumlah Pengguna Facebook dan Twitter di Indonesia? CNN Indonesia", http://www.cnnindonesia. com/teknologi/20150327061134-185-42245/berapa-jumlahpenggunafacebook-dan-twitter-di-indonesia/, diakses 1Agustus 2017

Sobur, Alex, 2004, Semiotika Komunikasi. Bandung : PT Remaja Rosdakarya.

Wella, 2013, Pengaruh ilustrasi visual meme "Rage Face" terhadap frekuensi kunjungan website 9GAG, Jakarta: Universitas Kristen Petra

http://www.kompasiana.com/dewi_puspa/wanitamakin-lirik-rodadua_54f38a7d7455137f2b6c7b1b, diakses 20 Agustus 2017

http://www.kekenaima.com/2016/11/i-support-women-ride-safequeenrides.html, diakses 26 Agustus 2017

h t t p s: / / a pji i.or.id/s u r vei 2017 / d diakses 26 Agustus 2017 